\title{
PANTHEISM IN SPINOZA AND THE GERMAN IDEALISTS
}

\author{
F. C. COPLESTON, S.J., M.A.
}

Is an essay on pantheism Schopenhauer observes that his chief objection against it is that it says nothing, that it simply enriches language with a superfluous synonym of the word "world." It can hardly be denied that by this remark the great pessimist, who was himself an atheist, scored a real point. For if a philosopher starts off with the physical world and proceeds to call it God, he has not added anything to the world except a label, a label which, if we take into account the ordinary significance of the word "Grod," might well appear unnecessary and superfluous: one might just as pertinently say that the world is the world as that the world is God. Neither the Jew nor the Christian nor the Moslem understand by "God" the physical world, so that, if someone calls the physical world God, he cannot be taken to mean that the world is God according to the Jewish or Christian or Moslem understanding of God. Does he mean any more than that the physical world is ultimately self-explanatory, that no Cause external to the world, no transcendent Being is requisite or admissible, i.e. that there is no God? If that were all there is in pantheism, the latter would indeed be indistinguishable from atheism, and those who called Spinoza an atheist would be fully justified.

As far as Spinoza is concerned, I do not hesitate to say that his system, when looked at under one of its aspects, is indeed atheistic, and that, so far as that aspect is concerned, the word "God," which he employs so frequently, is a superfluous label. Some of those who accused Spinoza of atheism had a personal and interested motive in doing so, for, having undergone the influence of Descartes and realising the apparent connection between Spinozism and Cartesianism, they were eager to dissociate themselves from a system, which, at least superficially, seemed to have its roots in the philosophy of the Frenchman, and what more effective means could they employ to dissociate themselves from that system than abuse of its author? 1 But even if some of those who accused Spinoza of atheism had an interested motive in doing so, it does not follow that

I I do not say this out of any hostility to Cartesians, long since dead, nor, of course, do $I$ accuse them of any insincerity: their attitude was only natural in view of some consequences which, as Leibniz hints, might seem to follow from Descartes' doctrine. 


\section{PANTHEISM IN SPINOZA AND GERMAN IDEALISTS}

this judgment was necessarily without foundation. From one point of view Spinozism can be regarded as the utmost possible generalisation of the attitude of contemporary science towards the material world, as a linking up of all phenomena, physical and psychical, past, present and to come, in one great interconnected system, one intelligible and self-dependent cosmos. Looked at from this point of view, Spinozism is atheistic, for to call the cosmos God is to denude the term God of all its traditional significance and to render it meaningless. If the cosmos is "God," there is no God, and the man who declares that there is no God is an atheist. Thus, if taken in its deterministic, mechanical, scientifico-mathematical aspect, Spinozism is an atheistic system.

This aspect, however, is not the only aspect under which the philosophy of Spinoza can be regarded. Beneath the logical schematism of this massive system, with its definitions and axioms, its propositions and proofs, its Q.E.D.'s and its corollaries, which appear so cold and dispassionate, there can be heard the cry of a Weltschmerz, of a hunger for the Infinite. In the Tractatus de intellectus emendations Spinoza speaks of the vanity and futility of the pursuit of riches or fame or pleasure, and declares that it is only love for a thing eternal and infinite which is the source of unmixed joy, while his ethical system culminates in the amor intellectualis Dei. It is true that Spinoza's philosophy is extremely intellectualist, and that his conception of love as an active and rational emotion is scarcely what we ordinarily understand by the term love: but it is also true that there is discernible in his thought and attitude a reaching out beyond the transitory phenomena of experience to the Infinite Being of which they are the manifestation. God, for Spinoza, was certainly not the personal Creator-God of orthodox Judaism, but He was the Infinite, the ultimately real, possessed of an infinity of attributes, and the character of infinity, the ascription to God of attributes unknown to the human mind, most probably permitted a psychological attitude towards the infinite Substance which Spinoza could hardly have adopted towards the actual world of experience considered precisely as such. In his Ethics Spinoza starts with God, the self-explanatory Substance, the principle of intelligibility, so that God was, in a sense, something more real than His manifestations or modes, more ultimate, as though God were the ocean and God's finite modes, the existential duration of which is transitory, the waves and ripples on the ocean's surface. Substance may not exist apart from its successive modifications, determined in their nature and succession, but it is easy to see that, in so far as Spinoza's mind was fixed on the infinitude of the Substance, the phenomenal world could take on the appearance of comparative unreality: God was All. From this standpoint Spinoza 


\section{PH I L OSO P H Y}

can scarcely be called an atheist, for, though he does not conceive God as Spirit, it is the world, rather than God, that he suppresses, "'Spinozism," says Hegel, "might really just as well or even better have been termed Acosmism (than atheism), since according to its teaching it is not to the world, finite existence, the universe, that reality and permanency are to be ascribed, but rather to God alone as the substantial."

But if there is an aspect of Spinozistic pantheism under which it cannot simply be termed atheistic, it does not follow that it escapes from other objections which can be levelled against it precisely in so far as it is pantheistic and not atheistic. For example, if one starts with the infinite Substance, God, it is impossible to demonstrate that the modifications of Substance must follow or to explain their - appearance, for an infinite Substance will, ipso facto, realise all its potentialities in undivided simplicity: to speak strictly, it will have no potentialities, but will be Act pure and simple. I am not, of course, demanding that Spinoza should deduce the actual series of particulars, for he observes that to do this is beyond the power of the human mind, which is a reasonable answer, even on the pantheistic hypothesis. But, since it is his express teaching that contingency has reference only to the imperfection of our human and limited knowledge, it follows that the modifications of Substance are in themselves determined and necessary, not contingent, and one is justified in demanding a demonstration of this necessity in general, for it is essential to the pantheistic position. Again, when Spinoza distinguishes the different levels of cognition, from imaginatio up to the intuition of the Totality, he does not explain how inadequate ideas can exist at all. If they exist, then they must be referred ultimately to God, since all that exists is in God: but how can God have inadequate ideas, even under and through His finite modifications? The notion that one is a person distinct from God may be an incorrect notion, but, if so, how does it come about that such a notion can be formed and is frequently formed? Moreover, the difficulties attending Spinoza's ethical system are obvious to all serious students of his philosophy as a whole. Blyenbergh's controversial letters may or may not have been tiresome productions, but, as the late Professor de Burgh remarked, his objections remained unanswered for the very simple reason that they were unanswerable. Of course it may well have been better for Spinoza to be inconsistent rather than consistent, since his rational ethic gives evidence of his personal highmindedness, but internal inconsistency cannot be considered a testimonial for a system of philosophy. Spinoza, unlike Descartes; did not start from a fact of experience but from a hypothetical unique Substance, a metaphysical hypothesis not given in experience, with the result that he had, "absent-mindedly" (as Kierkegaard 
remarked apropos of Hegel), to forget and leave unexplained data of experience which obviously needed explanation. Leibniz, on the other hand, though convinced, like Spinoza, that Reality is an intelligible and significant system, was led by his regard for experience, for individuality, for activity, to postulate a different kind of unity from that postulated by Spinoza, maintaining both the plurality of individual beings and the significance and intelligibility of the hierarchy of being as a whole.

The hostile attitude to Spinozism which prevailed for a long time gave way to a new attitude towards the end of the eighteenth century, and Novalis' description of Spinoza as the "God-intoxicated man" is well enough known. The Romantics, however, tended to look on Spinoza through their own coloured spectacles. That the latter's logical schematism was shot through and enlivened, for Spinoza himself, by a religious awe in presence of the Infinite and by a conformity to the "Divine Will" is, as I have suggested above, probably true: but any personal piety there may have been on the philosopher's part should be traced, not so much to his system and its effect as to his upbringing in a Jewish family and to a transference to Deus-substantia of the psychological attitude that an orthodox Jew would manifest towards the Creator-God of Judaism. There is little indication in the pages of Spinoza's writings that he felt any of that emotion in the face of phenomenal Nature which romantic poets have shown (though that, of course, does not prove that he never felt such emotion): he speaks little, if at all, of the beauty of Nature. He was doubtless filled with admiration and wonder at the sight of the reign of law, at the majesty of the cosmos as an eternal, significant and coherent system, just as he found that he could not be satisfied with any merely finite good: but we should certainly not look to the Ethics for the poetic, quasi-mystical emotion manifested by romantic poets towards the natural Totality, an emotion partly inspired by the keen perception of natural beauty, as also by a feeling, not essentially based on science and mathematics and logical reasoning, of one Life pulsating in Nature as a whole and in the human frame. If one can safely refer to Faust's famous declaration to Margarete without laying oneself open to the charge of having dubbed Goethe a "romantic," Spinoza would never have said, Gefühl ist Alles: it was not for nothing that he spoke of the love of God as the intellectual love of God. The revival of interest in Spinoza dates from the time of the correspondence between Jacobi and Mendelssohn, and it is only natural for us to-day to look back on his system in the light of German philosophy: but we should do well to remember that Spinoza's acquaintance was with Jewish Neoplatonic speculation, with Cartesianism, and with a certain amount of Scholasticism. The conception of the divine Substance, modified 


\section{P H I LOS O P H Y}

in its manifestations, might be termed a conflation of the Neoplatonic emanation theory with the Scholastic doctrine of created substance and accidents, a conflation made and thought out in face of the Cartesian dualism, though itself strongly influenced by Cartesian themes. Spinoza was a philosopher who was convinced that the intellect can find its satisfaction only in the Infinite, and in this: respect his thought, despite its mathematico-scientific aspects, betrays some kinship with that of Plotinus and St. Augustine: but he was not an aesthetic romanticist.

When one turns from the philosophy of Spinoza to that of the elder Fichte, it is as though one were transported from a gallery of sculpture to the stand at an Olympic race: the atmosphere of quiet contemplation gives place to one of energy and activity. Generalisations, of course, are often inaccurate and loose, and Spinozism cannot justly be called a merely static philosophy, while there is more in the system of Fichte than an emphasis on action; but it is probably not fanciful to see the difference in character between the retiring Jewish lens-grinder and the patriot who delivered the Addresses to the German People and wished to go as philosophic chaplain to the Prussian troops in the war of liberation reflected in their respective philosophies. Moreover, the dominion of the geometrical method and of mechanical physics had been invaded by a new. sense of historical becoming, of development, which was, be it remarked, partly due to the work of Leibniz, in spite of those who would see in his philosophy nothing but logic and mathematics exceeding their limits. German speculative idealism was certainly influenced by Spinoza, but the Spinozistic pantheism was rethought in a more dynamic form and (a most important point) it had passed through the fire of the Kantian Critique, a fact which rendered a new approach inevitable, for the post-Kantian idealist would be unable to start from the concept of substance.

Kant affirmed the transcendental ego as a logical condition of the unity of experience, though it was not for him an object of theoretical knowledge. Fichte seized on the idea of the transcendental ego (as the I-subject, which is always presupposed by the I-object, but never itself becomes object) and tried to deduce therefrom empirical consciousness. Protesting that the Kantian thing-in-itself was an unnecessary piece of luggage, once given the Kantian Critique, he declared that by denying the existence of the thing-in-itself he was but rendering Kant consistent with himself, a declaration which may have been largely justified in fact, though Kant himself rejected the claim. However, whether Fichte was fulfilling Kant or maiming him, he obviously could not, in making the object the creation of the subject, make it the creation of the empirical subject as such, since it is clear enough that the object is something given to the 
empirical subject, something which it finds in existence, with which it is confronted. He had, therefore, to derive the object, not from the empirical subject but from the meta-empirical subject, the transcendental ego. The latter, then, became his starting-point, and from the transcendental ego he attempted to deduce dialectically the division of experience into the empirical subject and the empirical object. Kant's logical condition of experience thus became a real and ultimate principle of explanation in regard to human experience.

As far as a mere theory of knowledge is concerned, as far as there is question only of a logical analysis of experience, one might treat the transcendental ego as a principle of explanation without committing oneself to any definite statement as to its ontological status, without affirming that there is one transcendental ego or a plurality, without coming down definitely either on the side of idealistic monism or on that of pluralism. After all, Aristotle taught the existence of an active intellect, but, so far as we are concerned, it remains doubtful whether he postulated one active intellect common to all men, as the Averroists interpreted him, or ascribed an individual active intellect to each individual man, as St. Thomas Aquinas interpreted him. But it is obviously a short step to take from the assertion of the transcendental ego as ultimate principle in the analysis of experience to the assertion that it is the Transcendental Ego with capital letters: in fact in a fully idealist philosophy this transition would seem to be inevitable, if solipsism is to be avoided, and Fichte stoutly denied that he was a solipsist. In Fichte's system, therefore, Kant's transcendental ego blossomed out as the Absolute Ego, the ultimate source of finite subjects and objects (or rather of finite subjects and of finite objects via the former), the modest Kantian theory of the subject's active constitutive function in knowledge turning into a system of Transcendental Subjective Idealism.

It is not, however, very easy to see exactly how Fichte regarded the relation between the finite consciousness and the Absolute Ego. It is obvious enough that he could not teach pantheism in the sense "of simply identifying Nature with God and God with Nature, since Nature was, for him, no more than object-for-a-subject: in an idealist system of the type propounded by Fichte naturalistic monism was out of the question and also substantial pantheism. He could not identify God with Substance, if substance was something secondary and derived: the concept of substance was the result of the application of an a priori form, and that form was derivate and not ultimate. (This inability to admit the substantiality of God was one of the reasons why Fichte was accused of atheism, a charge the justice of which he indignantly denied.) But what was the precise relation between the Transcendental Ego and the finite 


\section{P H I L OS O P H Y}

ego? Was the latter a canalisation, as it were, of the former, an emanation of the unitary "Ego? Such would be the pantheistic interpretation, and there is certainly much in the philosopher's writings which would seem to make such an interpretation not only justifiable but also inevitable. Yet it must be remembered that the reason why the world is posited is, for Fichte, that it should serve as a field for free moral endeavour. There is one moral law, but it is manifested in the particular moral vocations of finite individuals, and, in so far as they fulfil their moral vocation, they contribute to the concrete realisation of the moral world-order. This fine conception. with its emphasis on moral activity and freedom, not only corresponded to Fichte's energetic character, but is also in conflict with any complete pantheism, since the latter is, logically speaking, deterministic in character. However, even if, as is probable, Fichte's deduction of the finite ego is justly taken to imply a kind of emanation or a self-diremption of the Absolute Ego within itself, he went on in later years to develop a more religious version of his system in which the Absolute Ego or Moral Will appears rather as the Absolute Being, of which finite egos are the manifestations, and to which they should strive consciously to return, though no individual is ever completely absorbed or swallowed up in God. There seems to be envisaged an unending approximation to God, reminiscent of Kant's theory of the asymptotic approach to moral perfection: Fichte was too energetic in character to yield to the fascination of the idea that all individuals are at length completely merged in the one Being. He would not, it is true, allow that God is "personal," but that was because he regarded the ascription of personality to God as necessarily anthropomorphic, because he thought of God as supra-personal, which is not the same thing as infra-personal.

The strongly religious and more contemplative aspect of Fichte's later philosophy appears especially in his so-called popular works, works which Hegel dismisses in his History of Philosophy as edifying but irrelevant from the philosophic viewpoint. But though the lectures to which I refer may not have been composed from a standpoint which Hegel would recognise as adequately speculative, and though it is the standpoint of the Wissenschaftslehre which one has to take most into account when one is considering the historical connection between Fichte, Schelling and Hegel, the lectures are of some importance when one is considering the system of Fichte by itself, for they indicate the direction taken by the philosopher's thought in his later years. They smack somewhat of the pulpit, but all three of the great German metaphysical idealists began with the study of theology, and Fichte often tended to adopt the role of a philosophic preacher. Whether the character of his later works should be taken to indicate an advance from idealistic 


\section{PANTHEISM IN SPINOZA AND GERMAN IDEALISTS}

pantheism to unequivocal theism or not, is obscure; but in my opinion Fichte never was an out-and-out pantheist. That his idealist standpoint effectually prevented his asserting pantheism of the Spinozistic brand, I have already noted, as also that his insistence on freedom and morality appears to be inconsistent with any rigorous form of pantheism. Leaving out of account the very great differences in content and atmosphere between their systems, one might institute a comparison between Fichte's thought, at least in its more developed stages, and that of Plotinus. The latter did not believe in free creation out of nothing and employed the metaphor of emanation to express the procession of subordinate hypostases, and ultimately of the world, from the One, but he insisted that the One was not in any way diminished through the emanation. So Fichte, in my opinion, while not prepared to accept literally the Christian doctrine of creation, did not believe that the Absolute is diminished or changed through the emergence of finite consciousnesses. In other words, neither the system of Plotinus nor that of Fichte can be termed unequivocal theism or unambiguous pantheism. If immanence receives the emphasis in Fichte's earlier thought, the transcendence of the Absolute is more emphasised in his later development, and that is probably as far as we can get.

The system of Fichte was a system of transcendental subjective idealism, characterised by a strongly marked ethical interest: in the system of Schelling a romantic view of Nature is substituted for Fichte's theory that Nature is a mere means to moral endeavour, and the latter's dynamic attitude gives place to one more contemplative in tone, artistic creation and aesthetic experience receiving the emphasis rather than moral striving and self-conquest. To speak of "the system of Schelling" may occasion surprise in view of the fact that historians of philosophy have been accustomed to discover a number of philosophies held successively by Schelling; but, on the one hand, the stages of his thought do not constitute separate philosophical systems so much as the result of further reflection on positions already attained, so that they exhibit a more or less continuous process of development, while, on the other hand, it is the middle stage which is really characteristic of Schelling, more so than his earlier Fichtean standpoint or the somewhat bizarre speculations of his later years when he was trying to counteract the influence of Hegel at Berlin. I confine my attention, therefore, to the stage (or stages) represented by the philosophy of Nature and the system of Identity.

As he moved away from the position of Fichte, Schelling came to conceive of Nature as a meaningful organism, a totality, striving upwards towards consciousness under the impulse of the World-soul or principle of organisation in the cosmos. Nature is not the dead 


\section{P H I L OS O P H Y}

material of our duty, but is a dynamic process in which things are but transitory products of an endless becoming. There is one stream of Life in Nature, but Nature, which is always striving after the perfect representation of the Absolute, differentiates herself on various specific levels into those individuals, the succession and transitory character of which betray the fact that they are unsuccessful attempts to manifest the Absolute. In its highest production, however, human consciousness, Nature is enabled to turn back on herself and to realise her unity in reflection. The highest development of consciousness is achieved in artistic genius and its creations, for in the work of art the Infinite and the ideal are perfectly represented in finite form, and the synthesis of freedom and necessity is brought about.

If in his philosophy of Nature Schelling proceeded from the side of the object, in his system of transcendental idealism he started with the subject and tried to show how spirit issues forth from itself until it reaches its supreme expression in aesthetic experience and its fullest objectification in artistic creation, the two poles of spirit and matter, subject and object, being united in the work of art and perfectly fused together. Reflection on this finite union of spirit and nature led Schelling to the conception of the Absolute as Spirit and Nature in identity: the Absolute is the pure identity of Being and Thought, standing behind all finite manifestations, all differentiations, as the vanishing-point of all differences, the all-embracing and undivided Identity. (Schelling proceeded to introduce from Platonism an eternal world of Ideas, God's intuitions of Himself, the true things-in-themselves, which are the exemplars of all empirical things, and which it is the sublime function of the artist to represent in the concrete work of art.)

Schelling's conception of Nature as a totality, a living and dynamic process, a self-organising cosmos, was thoroughly romantic in character, as also was the position assigned to the artist, to aesthetic contemplation and the work of art. Of course, Schelling was influenced by other philosophers who could scarcely be classed as romantics (e.g. his theory of Nature below man as slumbering spirit is reminiscent of points in the Monadology of Leibniz, while his doctrine of the work of art as the synthesis of freedom and necessity is partly an attempt to settle a problem of Kant), but he was the great philosopher of the German romantic movement, fully imbued with the general romanticist worship of the Totality. For the logical and mathematical schematism of Spinoza he substituted the conception of life, of movement, of Nature as a living unity, a self-unfolding organism, and in this he may be said with justice to have constructed a romantic and poetic Spinozism. But whereas the intuition postulated by Spinoza was primarily an intuition of the 


\section{PANTHEISM IN SPINOZA AND GERMAN IDEALISTS}

Totality as an articulated system, of Substance in its manifestations, and of the modifications according to their place in Substance, Schelling's intuition of the Absolute was the intuition of a formless identity, a quasi-mystical apprehension of (to use Hegel's caustic phrase) the night in which all cows are black. In Schelling, as in Spinoza, we can see a certain desire for the Infinite, but it is significant that in the case of Schelling that Infinite is without form and void: he would have the Infinite, but it must be an Infinite in which all forms are indistinguishably merged, neither an infinite System nor infinite Form - a true romanticist. (In his later thought Schelling advanced to a theistic position, accompanied by various speculative extravaganzas, but it is not to my point to speak of his later theism.)

If Fichte's emphasis on the Subject and Schelling's emphasis on the Object may be said to stand to one another as respectively thesis and antithesis, it was left to Hegel to attempt the synthesis, and, whatever one may think of the Hegelian system as such, one must admit that he was admirably equipped for the task. This "bourgeois" professor, who acquired a vast store of erudition, patiently collected (even if his information was not always particularly accurate), was yet not overwhelmed by the weight of this intellectual baggage, but, with a truly astonishing power of synthesis, dialectical subtlety and imaginative insight, was able to carry the tout ensemble and to order it systematically in a grandiose and comprehensive philosophy. Kierkegaard remarked once that if Hegel had meant his system to be simply an intellectual tour de force, he would have been the greatest philosopher who ever lived, but as he meant it seriously he is merely a joke. Whether one agrees or not with Kierkegaard's sarcastic observation, it obviously presupposes that one understands what Hegel meant, and yet that is precisely the difficulty, to understand exactly what Hegel meant by his system. One can, it is true, understand without much trouble Hegel's view of the relation of romantic to classic art, or of reason to faith, or of the State to civil society, but to understand rightly, and to be able to feel sure that one understands rightly, his view of the relation between the world and God, that is not so easy. One can, I think, be certain that Hegel did not accept voluntary creation out of nothing "in time" (that he regarded as a theological Vorstellung), but the obscurity of his language renders it very difficult to see what he really believed concerning the world's relation to God. In such points to force an indubitable meaning out of Hegel's words is, as Ferrier observed, rather like trying to distil whisky out of a loaf of bread. In discussing the question of Hegel's theism or pantheism one is, then, hardly entitled to dogmatise, to assert that one's own interpretation is the only possible or reasonable interpretation.

Kant had asserted the partial constitution by the subject of the 


\section{P H I L OSO P H Y}

object as phenomenon, Fichte went on to assert the total constitution of the object by the subject (in the sense of the Transcendental Ego): Hegel accepted this general idealist position, though he did not accept the one-sided "subjectivity" of Fichte, but agreed with Schelling that Nature enjoys a more objective status than Fichte allowed her. The world, then, in its entirety, including the finite consciousness, is the product of the Cosmic Reason, the Idea, God. Thought cannot be reduced to matter, but we must not, as philosophers, remain in a dualistic position, so that matter must ultimately be reduced to, or be seen as proceeding from thought. Being indeed is primary, but ultimate Being, as Aristotle saw, is Thought, though we cannot be content with Aristotle's position, which leaves Thought, the Idea or self-thinking Thought, without any organic connection with the world save that of unconscious teleological attraction. One must utilise not only the Platonic conception of the Demiurge but also the Christian conception of the production of the world by God, provided that one realises (I speak for Hegel) that the notion of a free and voluntary act of creation on God's part is an instance of theological anthropomorphism or symbolism, admirably adapted for the religious consciousness, but inadmissible from the speculative standpoint of pure reason. The world, then, proceeds from the Absolute, but what is the Absolute? It is not simply Substance, as Spinoza thought, nor is it Schelling's formless identity: it is Reason or Mind, it is Being, but Being in its true nature as Idea. Plato lighted on a real truth, that true being is Idea, but he failed to work out the unity of the Idea or their relation to the world, while he separated the Ideas and Nous, and did not realise the dynamic, self-expressing character of the former. The Universal is indeed the truly real, but the Universal manifests itself in the particular.

Cosmic Reason, then, or the Idea or God manifests itself in the world of particularity, of finitude, imperfectly in Nature, perfectly in Spirit, above all in the universal philosophic activity of the human mind. In this activity the particularity of the individual is transcended, man rethinks the thought of God, apprehends the Divine Essence as what it is, i.e. thought, and God attains "existential" self-consciousness in and through the human spirit. Man is essentially spirit, but he has also his place in Nature, so that in man the synthesis of the Idea and Nature is achieved. The whole historical process in space and time constitutes the self-manifestation of the Absolute, but the Absolute, being Idea, can manifest itself adequately only in what is like itself, in universal thought, in the history of philosophy, which, as a manifestation of the Absolute, transcends in point of adequacy the sensuous manifestation in art and the symbolic representation in dogmatic theology. 


\section{PANTHEISM IN SPINOZA AND GERMAN IDEALISTS}

What, then, for Hegel is the precise relation of Nature to God? And what is the precise relation of the finite mind to the Worldspirit? Was he a pantheist, or was he not? Hegel, it is true, explicitly rejected the charge of pantheism, and we must suppose that he really attached some meaning to this rejection, and was not simply "dancing to the pipe of ministers," as Schopenhauer puts it; but it is no facile task to discover exactly what he did mean. He refused to identify this stone or that tree, i.e. the particular as such, considered in its particularity, with God; but did he mean to imply that the particular, considered precisely as such, is unreal, and that the real is objective Reason, God, alone? Or did Hegel suppose that "God" is simply the noetic structure of the world, the inside of the world, so to speak, which attains self-consciousness and selfreflection in and through the human spirit? In this case the Worldspirit would be little more than the universal activity of the human mind, considered as transcending the individual mind, subjective spirit, and the Hegelian system would perhaps be more properly termed an atheistic than a pantheistic system? Or did he maintain that the world is external to God, that God transcends the world ontologically, in which case he would be a theist?

That Hegel meant that God is simply the structural principle of Nature, which first attains the status of Spirit in man, is to me unthinkable. If he really thought this, he would not have been the idealist that he certainly was. Reason or the Idea must be, at least logically, prior to Nature, and Nature must proceed from the Idea. This is clearly taught by the doctrine of the dialectic. Moreover, it is a notorious fact that Hegel declared that the particular cannot be deduced. The critic may think that what Hegel should have said is that, though particulars are in principle deducible, in se, the human mind cannot deduce them (and in support of this it may certainly be urged that Hegel stated that philosophy is concerned with the universal and not with particulars), but what he actually said was, not that he could not deduce particulars, but that particulars could not be deduced. In other words, Hegel admitted an element of contingency in Nature: he insisted that Nature, precisely because of the element of contingency and imperfection, is an inadequate manifestation of the Absolute, that mindless Nature is but a stage on the road to the adequate manifestation of the Absolute as Spirit. But if Hegel was really no more than an atheist this element of particularity and contingency is left without any explanation, and it is inconceivable that Hegel was content to leave unexplained the presence of particularity as such, even if philosophy cannot deduce any given particular. It may be said that, for Hegel, the universal comprises the particular and that the universal, i.e. the whole system of universals which constitutes the Absolute is self- 


\section{PHILOSOPH Y}

explanatory, so that the particular requires no further explanation; but it is obvious that the universal does not comprise the particulars in such a way that it is confined to any given set of particulars (no more than the State is confined to any given set of individual citizens), so that the particulars must flow from the universal, and, if they flow from the universal, the latter is logically prior. The Idea, then, must be prior to the contingent world of particulars, even if it is partially manifested in that world, and in this case Hegel cannot have been an atheist. He may have been a pantheist or a theist, but he was certainly not an atheist.

Now, if Reason or the Idea is logically prior to Nature, and if at the same time creation through a free act of God is ruled out, the world must proceed timelessly from God (in the sense that no first moment of time can, even ideally, be assigned). God, the Idea, essentially tends to self-objectification, self-expression and manifestation: the Absolute, the Universal, reflects itself in the particular and the finite, the One being mirrored in the many. Nature is thus external to God in the sense that particulars do not belong to the Divine Essence considered precisely as such, but Nature is also the self-expression of God, God gone over, as it were, into externality, God in His otherness. God, by His very nature, tends to self-manifestation on the existential level, and the first stage of that manifestation is the Antithesis, mindless Nature, a stage on the road to the adequate manifestation of God in what is like Himself, in the universal thought of the human spirit. The human being, considered precisely as the individual Smith or Jones, with his purely private thoughts and aspirations, is not God (so Hegel denied that he was a pantheist), but the universal and developing thought of man, which transcends the individuals who think it, is the self-manifestation of God, progressively reflecting on the external level His undivided essential self-consciousness.

Admittedly this is obscure, but the Hegelian system must be obscure if it is, as I think it is, neither unambiguous theism not unambiguous pantheism. It is not unambiguous theism since the world proceeds from God by a necessity of God's nature (this is surely the ontological fact corresponding to the logical transition in the dialectical deduction), and this immediately suggests either emanation or a kind of self-diremption of the Absolute within itself. Again, there seems to be a tendency to identify the univeral thought of man, not merely with a self-manifestation of the Absolute on the external level, but with the actual self-consciousness of the Absolute. The Hegelian system, however, is not unambiguously pantheistic, and could hardly be so, since not only does Hegel admit an element of contingency in Nature, but derives Nature from the Cosmic Reason, so that human reason also must be a derivative, even if 


\section{PANTHEISM IN SPINOZA AND GERMAN IDEALISTS}

the Cosmic Reason works in and through the human reason. The Idea is prior, mindless Nature and the human spirit proceed from the Idea: the universal and rational development of Nature and Spirit are alone truly significant and real, but the element of imperfection in Nature and the particularity in the life of subjective spirit are existential facts, facts which can only be explained if, although God is at the heart of Nature and the human mind, giving them significance, the imperfection of Nature and the finitude of the particular human mind are due to their being an external expression of God or the Idea.

In any case, even if Hegel's system was fully pantheistic, he did not lay himself open to Schopenhauer's charge that pantheism is simply a masked atheism, for God or the Cosmic Reason would be the only Being. He would, however, lay himself open to another charge brought by Schopenhauer, to the effect that in so far as pantheism has a meaning which is not already contained in atheism, it is an absurdity, since it starts with the notion of God, borrowed from theism, and then goes on to depict God as transforming Himself into the world as we know it. And would not Schopenhauer be right? If one starts with the Absolute and then depicts the history of the world and of man as the Golgotha of the Absolute, one thereby tends to cancel out the idea of God with which one started: not only does God become the eternal Romantic, but $\mathrm{He}$ becomes also the cosmic Sufferer. Yet in point of fact Hegel does seem to allow a distinction between God and Nature, as I have already indicated, and between God and the finite consciousness. He could not possibly identify God and the finite consciousness tout court, since Nature obviously does not proceed from the finite consciousness as such, so that God must at least be more than finite consciousnesses taken together. Further, as God or the Idea manifests Himself or itself, not only in and through the finite consciousness but also to the finite consciousness, there must be some real distinction between them. Whether the finite consciousness is immortal or not, is another question (Hegel does not appear to have troubled himself much about the matter), but, while the finite consciousness exists, it cannot, as a particular consciousness, be called God: it is in God but it is not God. Hegel's notion thus seems to me to be rather one of panentheism than rigorous pantheism-a hybrid of theism and pantheism, an attempt to have one's cake and eat it at the same time, largely due to the attempt to force theism into the framework of a deductive system. If a philosopher starts with God and proceeds to deduce the world, even if only in essence, some form of pantheism is the logical consequence; but the resulting pantheism will bear far more resemblance to theism if he starts with the idea of God as infinite Subject or as Reason than if he 


\section{P H I L OS O P H Y}

starts with the idea of God as Substance and proceeds to deduce more geometrico. It is perhaps significant that some orthodox theists have at times attempted to "baptise" the Hegelian system, whereas I am not aware of any orthodox theists who have seriously attempted to baptise the system of Spinoza, even if (as is surely possible'with any great philosopher) they have found stimulus and interest in the content of his philosophy. 